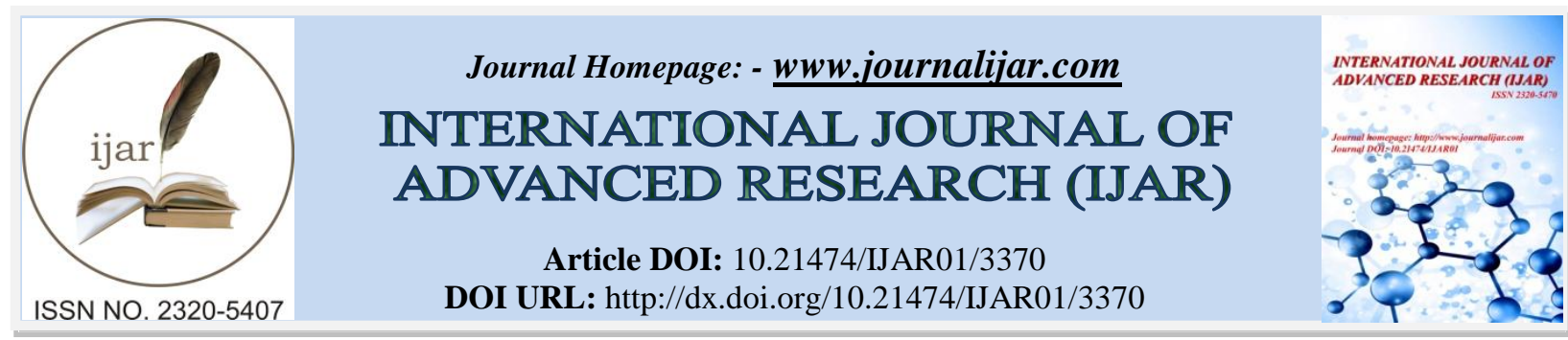

RESEARCH ARTICLE

\title{
THE EFFECT OF ORGANIZATIONAL SERVICE ORIENTATION, STRATEGIC LEADERSHIP AND STRATEGIC COMPETENCE ON THE ORGANIZATIONAL PERFORMANCE OF PRIVATE UNIVERSITY.
}

Lulu Setiawati S. E. M. Bus ${ }^{1}$, Prof. Budiman Christiananta Drs Ec. M. A. Ph.D ${ }^{2}$ and Lena Elitan Ph.D ${ }^{2}$.

1. Faculty of Economy, Pelita Harapan Surabaya University.

2. Faculty of Business, Widya Mandala Catholic University.

\section{Manuscript Info}

\section{Manuscript History}

Received: $\mathrm{xxx} x \mathrm{xx} x \mathrm{xxx} x \mathrm{xx} x \mathrm{xx}$

Final Accepted: $x x x x x x x x x x x x$

Published: $\operatorname{xxxxxxxxxxxxxxx}$

Key words:-

Organizational Service Orientation,

Strategic Leadership, Strategic

Competence, Organizational

Performance

\begin{abstract}
Competitions happened in many different fields of Industry, both in manufacture and service areas, including education industries around the globe. Universities need to create people who are competitive and have capabilities to match with the need of the industries. Having understanding about an organizational service orientation became important to the most of service organizations. Few researches relating to the study of organizational service orientation showed there were positive relationship between organizational service orientation and organizational performance. This study reviewed diverse empirical literatures on organizational service orientation, strategic leadership and strategic competence and their effects on organizational performance. This study find that having a service orientation will give better performance for an organization. The ability of strategic leaders to have strategic competence will also increase organizational performance.
\end{abstract}

Copy Right, IJAR, 2017,. All rights reserved.

\section{Introduction:-}

Nowadays competitions happened in many different fields of Industry, both in manufacture and service areas. Organizations need to have the right strategy to be able to survive and not only surviving but also expand in this highly competitive market for long term. The competitive challenges also effect education industries around the globe. Universities need to create people who are competitive and have capabilities that are match with the need of the industries. The ability of universites to improve their graduates quality through learning process become significantly important in recent years. Leaders at educational industries are expected to be more strategic in their leadership and lead their institutions to face the challenges. Universites are expected to be able to adopt the changes, develop and make improvement through their organization by creating their competitive advantges (Henderson \& Cocburn, 1994). The ability to create competitive advantages, will need strategic competence possessed by the universites' leaders. Baker et al. (1997) explained that strategic competence is "The accuracy/alignment between company business strategic and its external competitive environment." Strategic competence is defined as an ability to understand strategy (Fauré \& Rouleau (2011). Strategic competence is the main key for an institution to support its competitive position. Davies (2006) explained that universities who have the focus strategically were those able to use strategic approaches and strategic processes (include strategic planning) and they also have strategic leadership skills. 
Other challenge faced by the universities, especially private universities, relates to the services they give to their students. Educations as part of the service industries need to pay attention to the services that they give to their customers. Nowadays, students not only feel enough if they will only get the education itself but they also want the universites provide and give services that will satisfy them. Private universities need to have standards in giving the services to the students and each level of all the departments need to have the same understanding to practice the same standard. Handriana (1998) explained that perception of the same service standard accross the whole department and being understood by everyone inside the private university will produce service quality as the standard that they understand together. The same service standard can only be reached if everyone has the same perception toward the concept of service standard itself. It is part of the management responsibility to make sure that service standard desired is well communicated to all level in the organization. Lytle et al. (1998) explained the concept of organizational service orientation as a form of policies, practices and procedures to support and give reward for all behaviors that focus on service, to those who are able to give the best services. García et al. (2011) supported the work of Lytle that organizational service system has an influence toward job satisfaction. However, Little \& Dean (2006) work did not support the work of Lytle et al. (1998). They found that organizational serice orientation did not have significant impact toward service quality. Figure 1 shows the conceptual framework indicating the The effect of Organizational Service Orientation, Strategic Leadership and Strategic Competence on The Organizational Performance of Private Universities.

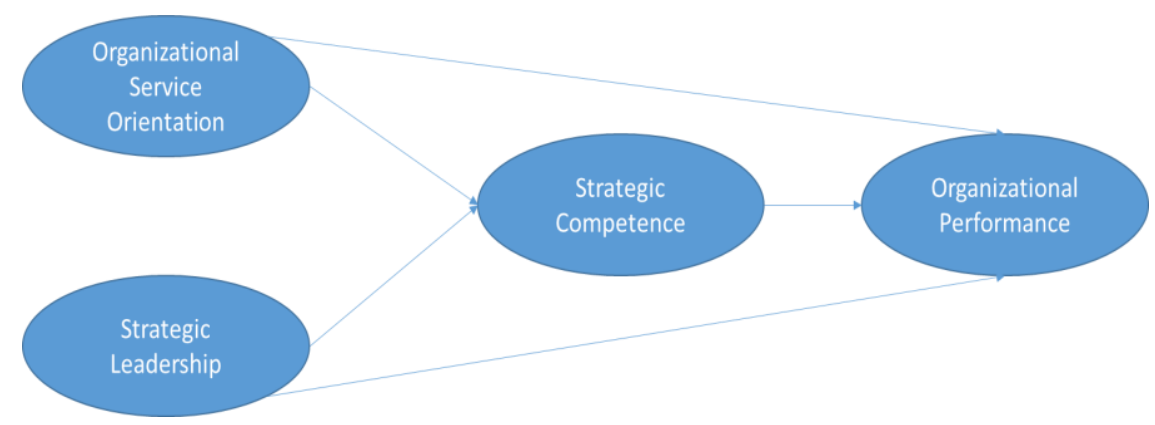

Figure 1:- Conceptual Research Framework

\section{Literature Review:-}

\section{Higher Education:-}

According to Indonesia Acts 2012 No 12 chapter 1(2), higher education is the level of education after high school, which include the programmes of diploma, bachelor, master, doctor, profession and specialist conducted by universities based on Indonesia cultures. Soehendro (1996) explained the basic foundations of universities in Indonesia consists of four functions:

1. Universities as a tool to produce labors that have specific qualifications to have productive functions in the society.

2. Universities as a tool to educate and train conceptors and researchers.

3. Universities as a tool to conduct learning process that is efficient, effective and productive ways.

4. Universities as a tool to pursue better life quality for the society.

Further, Soehendro (1996) explained that the functions attached to the universites are education, research and community service, when those functions are being conducted well will produce graduates. The graduates who will help the society through their knowledge and contribution.

\section{Organizational Culture in Services:-}

Culture has playing an important role in the success of organization both financial and position in the market. Peters \& Waterman (1982) in their book "In Search of Excellence" explained that each organization needs to have values and beliefs for it to survive and achieve success. Values and beliefs will influence organization policies and actions. Hofstede (1997) explained values as the center of culture in an organization. Values and norms were not something that we could observed directly, however we could see values and norms in practices, procedures and behaviors that 
were moved by values and norms. Beitelspacher (2011) mentioned service culture as a culture that focused to the customers.

"Service culture should be meant as a customer-centric culture, which aims at exceeding customer expectations, and is strongly focused on providing superior customer value. Service culture will lead to better customer perception of service quality, as well as having a beneficial impact on customer market loyalty, repurchase intentions and customer satisfaction."

When an organization tries to give the best service to the customers, even can do something beyond its customers expectation, then the action will bring customers' loyalty (Beitelspacher, 2011). Parasuraman et al. (1996) defined service quality as service received by customers that has fulfilled the expectation of customers toward quality.

\section{Organizational Service Orientation:-}

A concept about organizational culture which can described the ability of organization in giving excellent services to the customers is Organizational Service Orientation. Classical approach for quality management like TQM, in general is only focused on quality internally. TQM approach studies how the best activities conducted by the people inside the organization. Furthermore, other research about service quality mostly only consider the factor of service's experience received by customers (Mukherjee \& Malhotra, 2006). Very few discussions about service quality from customers perspectives. Organizational service orientation tried to see the quality of service not only based on the experience but also from the perspective of customers toward services. Organizational service orientation manifested in the behavior and attitude of employees that effect directly to the quality of service process given by customers. Lytle et al. (1998) in Urban (2012) defined organizational service orientation as:

"An organization-wide embracing of a basic set of relatively enduring organizational practices, policies and procedures intended to support and reward service-giving behaviours that create and deliver service excellence. At the visible level it is reflected by genuine attention to customer needs, as well as sharing, helping, assisting, and giving support to customers."

According to Lytle et al. (1998), organizational service orientation consist of four areas of service, which are:

1. Service Leadership Practices.

2. Service Encounter Practices

3. Service System Practices

4. Human Resoure Management Practices

Further, Lytle et al. (1998) in Urban (2012) tried to explain more for those four areas of service. Leadership in theory of management science is the main and first requirement needed for the growth of an organization. Besides leadership, the ability of the organization to have strong vision and long-term orientation also factors for the successful of organization. Lytle et al. (1998) also explained about Service Encounter Field as:

"Customer treatment and staff empowerment. How a service provider looks after customers is the first and the most important predicator of the quality perceived. In the literature output there is a conformity of opinion that says that to get delighted customers it is required to allow direct contact staff to act with very unconstrained manners. Only in this case will employees be able to react flexibility to customers' needs and provide superior service."

Customers will have satisfaction if employees can have good relationship with customers and have the authority to act in order to fulfill the need of customers. Employees need to have empowerment from the organization to make decisions. All services given by the organization to its customers come from a system within the organization. According to Deming, an expert in quality management (1994), inside the system there should be a potential to fix the quality. Lytle et al. (1998) explained three areas related to Service System Practices, which are:

1. Service failure prevention and recovery practices

2. Service standard communication practices

3. High levels of service technology adaptation

The other important factor in Organizational Service Orientation is the factor of human resource. Literature about organizational behavior, especially the study that related to human resource management influence how service orientation is studied. Lytle et al. (1998) explained that 
“An organization's ability to produce external service quality is directly related to issues of internal service quality. These issues are typically studied in terms of employee attitudes, personalities, beliefs, and behaviors. Hiring, training, and rewarding service oriented behaviors have a direct and positive influence on service quality and organizational performance. Therefore, an organizational service orientation would involve a focus on serviceoriented human resource management throughout the organization."

Wahlers \& James (1994) explained that accurate strategy in service quality is the important factor that will effect competitive advantage if planned and implemented correctly. Service quality is the confidence for the service received (Tjiptono, 2005). If private universities can create the right service quality as their strategy then they can create their competitive advantage. Costumer satisfaction is an aftersales evaluation, in which alternative chosen is giving the result as it is expected or beyond expectation to the customers (Tjiptono, 2005). Zeithaml in Chang \& Chen (1998) showed that service quality has a very strong impact to the customers' behavior, such as product loyalty, the willingness to pay more for the products and customers tend not to shift their preferences if they are happy with the services.

Homburg et al. (2002) and Walker (2007) also said that Organizational Service Orientation plays an important part for the success of the organization. Service orientation has a positive influence toward service quality given by the organization. Lytle \& Timmerman (2006) explained that service orientation, like service quality image and organizational commitment, has an influence to return on asset for banking sectors. Yoon et al. (2007) also found that service orientation influenced the characteristics of performance such as repeat buying, positive word of mouth for health industry. Organizational Service Orientation also stated as "common denominator" for the attributes of educational services industry to be responsible for customer satisfaction (Walker, 2007). Organizational Service Orientation plays an important role to achieve business performance at service organization. If employees happy and satisfied with their job, they will give a better service to their customers (Garcia et al., 2011). Organizational Service Orientation effect service quality and customers loyalty that will lead to better financial performance (Urban, 2012). However, Little \& Dean (2006) found that Organizational Service Orientation did not have any influence on the service quality at the telecommunication companies.

\section{Characteristics of Service Qualityin The Universities;-}

Lupiyoadi \& Hamdani (2006) explained four characteristics of service quality owned by universities, which are:

1. University is service organization, during the process of delivering the service will required supporting tools like: classrooms, chairs, tables, books and laboratories.

2. Service given will need the present of customers as users, where students as customers need to come to the institution to receive the service.

3. Receivers of service are people, so services at university is categorized as high contact system. Customers and suppliers will interact all the time for the process of delivering the service. Therefore, students as customers have to be part of the system.

4. The relationship with customers will be based on member relationship, where customers will become the member for a particular educational institution.

A good service quality for private universities will make students and society satisfy and they are willing to inform to others by having word of mouth promotion. When the service quality is good then automatically the number of applicants will increase. The improvement of service quality is expected to increase numbers of new students (Firmansyah et al., 2014). Gordon \& Partington (1993) mentioned three criteria in measuring service quality, which were outcome-related, process-related and image-related criteria.

\section{Leadership:-}

Leadership has become an important topic in the literature to study organizational behavior. Lee \& Chuang (2009) found that a great leader not only bring inspiration to his subordinates in improving efficiency, but also fulfill their need in the process to achieve organizational goal. Stogdill (1957) defined leadership as an individual behavior to lead a group to achieve the same target. Fry (2003) explained leadership as a strategy to lead by offering motivation that will build, improve staff's potential to grow and develop. Sanders \& Davey (2011) conducted the exposition for leadership theories based on their evolution concepts towards these categories leadership: trait theories, behavioral theories, contingency theories, transactional theories and contemporary (transformational) theories. The purpose was to identify main elements from effectiveness and leadership constructs and connected with effectiveness of 
organization. Sanders \& Davey (2011) said that those theories in general were able to explain the construct of effective leadership, however overall it was not found in the literature explicitly the connection that connected those theories into a model that link effectiveness of leadership and effectiveness of organization. Synthesis of leadership theories showed three important elements to build effective leadership, which are task focus, people focus and development focus (Sanders \& Davey, 2011). Task focus involved the process to achieve goals of the group (purpose, objective and result). People focus included consideration, participation in decision making, care for the need of subordinates, justice, respect, trust, fair rewards. Development focus included the period needed to set new pattern adjusted to the condition where organization operated. Effectiveness organization considered as main tool to connect leadership theory with the construct strategic leadership and effectiveness of leadership need to be defined in the context of effectiveness of organization if it wanted to be considered as something strategic (Lear, 2012). Sanders \& Davey (2011) used the term "meta-model" for strategic leadership because the framework that they used described several theories about strategic leadership and they tried to combine theories in a comprehensive paradigm that connect interpersonal relationship of those theories and the connectivity with effective leadership and effective organization. In meta-model, effectiveness organization used as the main measurement for effectiveness leadership.

\section{Strategic Leadership:-}

Hitt et al. (2005) in Serfontein (2009) said that strategic leadership is assumed as a visioner leadership because he is willing to take a risk. Strategic leadership assumes that visioner leadership and managerial leadership can fill in each other and strategic leadership will combine both equally. Strategic leadership has a belief in the ability of strategic leader to change the organization in order to fulfill the changing environment where an organization operated (Rowe, 2001). Strategic leadership is a combination of synergy between managerial leadership and visioner. It is the ability to influence others to have the willingness to make daily decisions which leads to the organization' s ability for long term and at the same time stabilize the short term finances (Rowe, 2001). Boal \& Hooijberg (2001) said that the core of strategic leadership involved the learning and changing process to have good managerial wisdom.

Strategic leadership at higher education will always involved the moral purpose of the organization, which is a question: " why we do what we are doing now?". The important key for leaders at private institutions who take the strategic role that they need to have a mindset change to move further from details operational activities perspective to develop a comprehensive and wide organizational perspective. Strategic leader at private institutions in three to five years, need to be able to see and identify their main theme for their long term development which they want to achieve. Then, plan backward those plans to their yearly plan (Davies \& Davies, 2010). Davies (2006) said schools which were able strategically were those who could act effectively from education side in the short term, however they also have clear framework and able to process the framework into goal and moral vision expected by the organization both in medium and long run period. Nthini (2013) said that there was a high correlation between strategic leadership and customer satisfaction, return on investment, net profit margin and low employee's turnover. An effective strategic leadership will lead to the improvement of organizational performance.

\section{Personal Attributes of Strategic Leader:-}

Davies\& Davies (2010) explained three characteristics of strategic leader:

1. Strategic leaders are strategic thinkers

2. Strategic leaders are strategic learners

3. Strategic leaders are values driven

Strategic thinking is a tool to develop a strategic perspective that see things from different perspective. Garratt (2003) gave explanation about strategic thinking as:

"Strategic thinking is the process by which an organisation's direction-givers can rise above the daily managerial processes and crises to gain different perspectives...Such perspectives should be both future-oriented and historically understood. Strategic thinkers must have the skills of looking...forwards...while knowing where their organisation is now, so that wise risks can be taken while avoiding having to repeat the mistakes of the past."

Strategic leader is also someone who will lead in learning. If a leader does not seeking new knowledge all the time then he will be considered fail to bring the organization to develop and the most important, he fails to become a model for others. Hughes \& Beatty (2005) explained the learning process for the strategic leaders, which are:

1. Looking at the big picture-what can I learn from the broader environment? 
2. Looking for patterns over time-how can I learn from data dan find patterns in the data in order to extract useful information?

3. Looking for complex interactions-how can I synergise and learn from interrelationships?

4. Understanding what cause what-learning that it may be more complex than it seems!

5. Making time for reflection!

Strategic process also needs to have the base of values and beliefs. Bennis \& Nanus (1985) in the classical view about vision explained that the creation of a vision and its meaning were the characteristics that shaped a leader. Bennis \& Nanus explained that by focusing attention on a vision, the leader operated on the emotional and spiritual resources of the organization, on its values, commitment, and aspirations. Leaders often inspired their followers to high levels of achievement by showing them how their work contributes to worthwhile ends. It is an emotional appeal to some of the most fundamental of human needs-the need to be important, to make a difference, to feel useful, to be part of a successful and worthwhile enterprise. Brubaker (2005) explained that leader who can share his vision clearly and can be trusted will "Create a condition where others will feel inspired and have commitment toward something bigger from themselves."

\section{Competencies:-}

\section{Spencer \& Spencer (1993) defined competencies as:-}

An underlying characteristic of an individual that is causally related to criterion-referenced effective and/or superior performance in a job or situation. Underlying characteristic meant "the competency is a fairly deep and enduring part of a person's personality and can predict behavior in a wide variety of situations and job tasks"; causally related meant, "a competency causes or predicts behavior and performance"; and criterion-referenced meant "the competency actually predicts who does something well or poorly, as measured on a specific criterion or standard"

According to Robbins (2001) competencies are an individual capability to do various tasks in a job. Veithzal (2004) added that the whole ability of individual consists of two factors which are intellectual ability and physical ability. Intellectual ability is the ability of someone that is related to IQ and EQ or relate to the intelligence in knowledge and emotion. Veithzal (2004) explained seven dimensions that shape the intellectual ability:

1. Numeric ability: the ability to count quick and accurate

2. Verbal understanding: the ability to understand what he reads, hears and connect one word to another word

3. Conceptual speediness: the ability to recognize similarities and different visual quick and accurate

4. Inductive logic: the ability to recognize logic sequence in problems and then solve the problems

5. Deductive logic: the ability to use logic and examine the implication of an argument

6. Dimension visualization: the ability to visualize how an object will look like when the setting is changed

7. Memory: the ability to keep and recall back past experiences

Vathanophas \&Thaingam (2007) explained the four basic characteristics needed for competencies:-

1. Knowledge, information owned by someone in a specific area

2. Skills, the ability to do physical and mental tasks

3. Traits, physical characteristics and consistent response for information and situation

4. Self-concept, include behavior, values or self-image

\section{Strategic Competence:-}

Sparrow \& Hodgkinson (2006) defined strategic competence as an ability to get, store, repeat, interpret and act based on relevant information to be able to survive at the long term and for the benefit of the organization. Grant (1996) mentioned that competency represents the influence of characteristics organization and individual. Competence makes the organization proactively able to recognize signals that identify weaknesses in the organization to be changed. Trejo et al. (2002) tried to measure competence by using an approach that focus on resources owned by organization. Competence development in organization has taken form in several development models. The model that commonly used is system approach or strategic human resources management. Boyatzis (1982) used system approach to display competence role in the market sector. Boyatzis (1982) said that organization has to try to reach efficiency. To be able to reach efficiency, organization need to have competencies, job demand and consistent organizational environment. If the three factors didn't support each other, it will make inefficiency occurred. 


\section{Seija Ollila (2008) explained about strategic leadership as follow:-}

Competence is a combination of skills which an indivudual can use to complete the given task. In this quickly changing world, competence is the foundation of durable success and forward-looking possibilities. Competence is based on knowledge, know-how and attitiudes, which are combined with cultural identity, shared visions organizational structure, and management processes

Organizational strategic competence will combined individual skill inside the organization with culture, vision, structure and management process within the organization. Durand (2000) defined competence as:

"A capability to act. New competence, which is tied to the changing requirements of the environment, is born in interaction with an individual and his/her working area. An organization tries to achieve the goals of building, exploiting and maintaining competence. Competence also refers to the willingness of an organization to maintain and coordinate organizational assets and capabilities to achieve the goals."

Therefore, building up a capability for an organization is a process, in which the organization is able to change its resources and facilities and looking at the readiness of that capability to coordinate and arrange so that the new way will be achieved (Sanchez \& Heene, 1997; Sanchez, 2001; Sanchez \& Heene, 2004). Strategy as a concept define willingness, objectives and direction to achieve what the organization need. Strategic management needs a systematic thinking process, connecting all interactive relationships and sees things comprehensively. Main objective is making sure an organization future vitality (Porter, 1996; Kirjavainen \& Laakso- Manninen, 2000; Hannus, 2004). When leadership has strong strategic competence, the organization will have a better performance (Lerner \& Almor, 2002). According to Sanchez (2004) Strategic Competence-based Management is a management process where tangible and intangible assets will be coordinated for their usage according to the goal the organization wants to achieve. Ansoff (1984) and Butler et al. (1991) explained that in the process of making the strategies, culture values also influence and the process will also evaluate the current strategies and measure how the development of the new strategies. Knight (2001) explained about strategic competence as a function of main strategic such as: R\&D, product quality development, marketing and distribution. Alhawari \& Al-Jarrah (2012) defined strategic competence into four competencies, which are: (1) Shared vision (2) Cooperation (3) Empowerment (4) Innovation. Sveiby (1990) described competence of an organization into three main components:

1. Human Capital is the shared knowledge and competence that is connected to working tasks

2. Work Motivation and Ability

3. Commitment

Ollila (2008) explained about the competence in a way that easy to be understood in the concept of human resource, which was:

"The success of an organization is the consequence of human actions. In human capital, individual capacities make up one perspective. The social capital as a concept involves, beside human capital, a communal viewpoint which refers to the relations between human beings, customers, interest groups, management systems and norms. It is included in both the human and structural capitals and it can also be defined as a wider complex. When thinking about the societal consequences, trust and social capital are the key factors in communication, learning and innovations. The structural capital is the data which belongs to an organization and includes procedures, systems, technology, and organizational structure."

\section{Organizational Performance:-}

Performance is a concept that is difficult to be disclosed explicitly because the performance concept is usually understood implicitly. Performance related to a specific concept will deliver specific approach or measurement (Firmansyah, 2014). Performance of private university is a result that should be able to measure. Performance for each individual in the private university influenced by the ability and willingness. According to Fishbein \& Ajzen (1995) in Firmansyah (2014) and Gibson (1994), the concept of theory of attitude showed that each behavior conducted because of intention. Every behavior triggered by certain intention. Intention that was not supported by situation, mostly would not become an action. Therefore, individual effort was the trigger to create work behavior so that a meaningful performance was also created (Firmansyah, 2014). Organizational performance talks about the ability of the organization to achieve what is the purposes of the organization, like higher profit, product quality, increase of market share, better financial result and the ability to survive at a certain period of time by using the right strategy to act (Koontz \& Donnel, 1993). According to Alwi (2009), measurement of employee performance is the 
result of comparison between the actual and expected employee's performance. Dessler in Alwi (2009) explained several factors that can be used as tools to measure the performance of lecturers, those are:

1. Work quality, accuracy, appearance

2. Work quantity, number of outputs and contributions

3. Supervision needed, suggestion and improvement

4. Timely attendance

5. Consensus, maintenance of the facilities used

Further, McGrath \& MacMillan (2000) and Teece et al. (1997) explained that there was a relationship between leadership style and organizational performance. Effective leadership behavior will facilitate performance increase at times when organization facing new challenges. Griffin (1987) described performance as organization being effective and shows level of productivity gained from the resources owned by the organization. According to Prieto and Revilla (2006) performance can be categorized into two which are financial and non-financial performance. Performance measurement needs to be done in more comprehensive method.

\section{Performance Measurement:-}

Organizational performance is an indicator that can be used to measure achievement from goals and outcomes. Result from the performance assessment should be able to measured and assess clearly. Kaplan \& Norton (1996) explained that organizational performance has a broad concept and not only focus to profit or other financial performances. Modern business environment need different types of goal's orientation. New management approach is focused on stakeholder's perspective (Atkinson et al., 1997; Berman et al., 1999; Harrison \& Freeman, 1999; Hillman \& Keim, 2001; Sirgy, 2002; Riahi-Belkaoui, 2003; Tangem, 2004). The involvement of stakeholders is to make sure that organizational performance is will not only be looked at the financial indicator.

The first method used to evaluate individual performance and now being used widely at the universities, introduced by Armstrong \& Baron (1998). Performance appraisal also known as merit rating. This method is an organization mechanism to measure the performance of individuals to make sure that each member of the organization doing what organization wants them to do. Hernaus et al. (2008) measure the organizational performance by looking at the stakeholder perspective that focused on four perspectives, which are: (1) Financial's view, (2) Employee's view, (3) Supplier's view, (4) Customer's view. Perspective used similar to the approach of balance scorecard introduced by Kaplan \& Norton (1996). The difference between the two approaches is, Kaplan \& Norton looked at Internal Business Process while Hernaus et al. (2008) approached it from the perspective of Supplier's view.

\section{Conclusion:-}

This paper analyzed the effect of Organizational Service Orientation, Strategic Leadership and Strategic Competence on the Organizational Performance at Private Universities in Indonesia. There were many studies have been conducted to measure the factors that affected organizational performance. Researchers have examined that even on the manufacture companies, the variable effected the increasing of performance not only product's quality but also services that the organization given to their customers. In order for the organization to give the excellent services, all the members of the organization must understand the important of service factor to their customers. Organization also needs to have leader who has a leadership skills that will enable him/her to think strategically and able to make strategic decision so what the organization wants toward service excellent will be achieved.

This paper showed that there is strong relationship between Organizational Service Orientation and Organizational Performance. Service orientation influenced the characteristics of performance such as repeat buying, positive word of mouth (Yoon et al., 2007). Organizational Service Orientation plays an important role to achieve business performance, especially at service organization. If employees happy and satisfied with their job, they will give a better service to their customers (Garcia et al., 2011). Research found that there was a high correlation between Strategic Leadership and customer satisfaction, return on investment, net profit margin and low employee's turnover (Nthini, 2013). An effective Strategic Leadership will lead to the improvement of Organizational Performance. There is also strong relationship between Strategic Competence with Organizational Performance. Research found when leadership has strong competence, it will lead to the increase of Organizational Performance (Lerner \& Almor, 2002). This research wanted to add the previous studies related to the Organizational Service Orientation, Service Leadership and Service Competence toward the Organizational Performance on higher education organizations. Moreover as an organization in higher education, there will be more direct contact with customers, compare to the other organizations. 


\section{References:-}

1. Alhawari, S., \& Aljarrah M. (2012). The Impact of Knowledge Management Processes on the Improve of Strategic Competence: An Empirical study In Jordanian Insurance Companies, International Journal of Trade, Economics and Finance,1(3), 9-45.

2. Alwi, S. (2009). Manajemen Sumber Daya Manusia Strategi Keunggulan Komparatif. Yogyakarta: BPFE.

3. Ansoff, H.I. (1984). The Handbook of Strategic Management, Otava, Helsinki.

4. Armstrong, M., \& Baron, A. (1998). Performance Management. The New Realities. London: Institute of Personel and development

5. Atkinson, A. A., Waterhouse, J. H. \& Wells, R. B. (1997). A Stakeholder Approach to Strategic Performance Measurement. Sloan Management Review, 3(38), 25-37.

6. Baker, J.C., Mapes, J., New, C.C. \& Szwejczewski, M. (1997). A hierarchical model of business competence.Journal of Manufacturing Technology Management, 8(5), 265-272.

7. Beitelspacher, L.S., Richey, R.G. \& Reynolds, K.E. (2011). Exploring a new perspective on service efficiency: service culture in retail organizations. Journal of Services Marketing, 3(25), 215-228.

8. Bennis, W. \&Nanus, B. (1985). Leaders, New York: Harper Row.

9. Berman, S. L., Wicks, A. C., Kotha, S. \& Jones, T. M. (1999). Does Stakeholder Orientation Matter? The Relationship Between Stakeholder Management Models and A Firm Financial Performance, Academy of Management Journal, 5(42), 488-506.

10. Boal, K.B. \&Hooijberg, R. (2001). Strategic leadership research: moving on. Leadership Quarterly, 11(4), Winter, 515-549.

11. Boyatzis, R.E. (1982). The competent manager: a model for effective performance. London: Wiley.

12. Brubaker, D.L. (2005), The Power of Vision, in D.L. Brubaker \& L.D. Colbe, The Hidden Leader (Thousand Oaks, CA: Corwin Press).

13. Butler, J., Ferris, G. \& Napier, N. (1991). Strategy and Human Resources Management. South-Western Publishing, Cincinnati, $\mathrm{OH}$.

14. Chang, T.Z. \& Chen, S.J. (1998). Market Orientation, Service Quality and Business profitability: a Conceptual Modeland Empirical Evidence, Journal of Service Marketing, 12(4), 246-264.

15. Davies, B. (2006). Leading the Strategically Focused School, London: Sage.

16. Davies, B. \& Davies, B.J. (2010). Educational Management Administration and Leadership, London: Sage.

17. Deming, E. (1994). The New Economics, The MIT Press, ISBN 0-262-54116-5, Cambridge, USA.

18. Durand, T. (2000). "Forms of incompetence", in Sanchez, R. and Heene, A. (Eds), Theory Development for Competence-based Management, JAI Press, Greenwich, CT, 69-95.

19. Fauré, B., \&Rouleau, L. (2011). The strategic competence of accountants and middle managers in budget making. Accounting, Organizations and Society, 36(3), 167-182.

20. Firmansyah, M.A., Christiananta. B. \& Elitan, L. (2014). The Effect of Organizational Citizenship Behavior (OCB), Total Quality Management (TQM), Technology Leadership and Service Quality on the Performance of Private Universities in Surabaya. Academic Research International, 5(2), 174-185.

21. Fry, L. W. (2003). Towards a Theory of Spiritual Leadership. The Leadership Quarterly, 14, 693-727.

22. Garcia, T., Varela, J., \& Del Rio, M. (2011). Organizational service systems: Antecedents and consequences. Tourism and Hospitality Research, 11, 67-82.

23. Garratt, B. (2003). Developing Strategic Thought (London: McGrow-Hill).

24. Gibson. (1994). Organisasi, Jakarta: Erlangga Press.

25. Gordon, G. \& Partington, P. (1993). Quality in Higher Education: overview and update, Staff Development Unit, Sheffield: University of Sheffield.

26. Grant, R. (1996). Prospering in Dynamically-competitive Environments: Organisational Capabilities As Knowledge Integration. Organization Science, 7 (4), 375-387.

27. Griffin, R.W. (1987). Management (Second Edition), Boston: Houhton Mifflin Press.

28. Handriana, T. (1998). Analisis perbedaan Harapan Kualitas Jasa Pada Lembaga Pendidikan Tinggi di Surabaya. Thesis tidak dipublikasikan, Yogyakarta: Program Pascasarjana Universitas Gadjahmada.

29. Hannus, J. (2004). The Keys of Strategic Success: Effective Strategies, Abilities and Function Models, Pro Talent Oy, Helsinki

30. Harrison, J. S. \& Freeman, J. S. (1999). Stakeholders, Social Responsibility and Performance: Empirical Evidence and Theoretical Perspectives", Academy of Management Journal, 5(42), 479-485.

31. Henderson, R. \&Cockburn, I. (1994). Measuring Competence? Exploring Firm Effects in Pharmaceutical Research. Strategic Management Journal, 15, 63-84. 
32. Hernaus, T., Skerlavaj, M. \&Dimovski, V. (2008). Relationship Between Organisational Learning and Organisational Performance: The Case of Croatia. Transformations in Business and Economics, 1-19.

33. Hillman, A. J. \& Keim, G. D. (2001). Shareholder Value, Stakeholder Management and Social Issues: What's The Bottom Line?, Strategic Management Journal, 2 (22),125-139.

34. Hofstede, G. (1997). Cultures and Organizations. Software of the Minds, Mc Grew-Hill, New York, USA.

35. Homburg, C., Hoyer, W.D.\& Fassnacht, M. (2002). Service Orientation of a Retailer's Business Strategy: Dimensions, Antecedents, and Performance Outcomes. Journal of Marketing, 66, 86-101.

36. Hughes, R.L. \& Beatty, K.C. (2005). Becoming a Strategic Leader (San Francisco: John Wiley).

37. Kaplan, R. S. \& Norton, D. P. (1996). Using the Balanced Scorecard to Work. Harvard Business Review, 10 (9), 134-147.

38. Kirjavainen, P. \& Laakso-Manninen, R. (2000). The Management of Strategic Competence: Knowledge and Competence of the Enterprise to a Source of Competition Advantage. Oy Edita Ab, Helsinki.

39. Knight, G.A. (2001). Entrepreneurship and Strategy in the International SME. Journal of International Management, 7, 155-171.

40. Koontz, H. \& Donnell, C. (1993). Introduction to Management. McGraw-Hill Inc., New York.

41. Lear, L.W. (2000). Management transformation in the public sector: a critical analysis of the importance of strategic alignment in effective service delivery within government structures. MBL thesis, University of South Africa, Pretoria.

42. Lee \& Chuang (2009). The Impact of Leadership Styles on Job Stress and Turnover Intention: Taiwan Insurance Industry as an Example. retrived on 14 February 2016 from: http://www.studymode.com/essays/TheImpact-Of-Leadership-Styles-On-723980.html.

43. Lerner, M. \& Almor, T. (2002). Relationship among Strategic Capabilities and The Performance of Womenowned Small Ventures. Journal of Small Business Management, 40(2), 109-125.

44. Little, M.M. \& Dean, A.M. (2006). Links between service climate, employee commitment and employees' service quality capability. Managing Service Quality, 5 (16), 460-476.

45. Little, M.M. \& Dean, A.M. (2006). Links between service climate, employee commitment and employees' service quality capability. Managing Service Quality, 5 (16), 460-476.

46. Lupiyoadi, R \& Hamdani, A. (2006). Manajemen Pemasaran Jasa, Jakarta: Salemba Empat.

47. Lytle, R.S., Hom, P.W. \& Mokwa, M.P. (1998). Serv*or: A Managerial Measure of Organizational Serviceorientation. Journal of Retailing, 4(74), 455-489.

48. Lytle, R.S. \& Timmerman, J.E. (2006). Service orientation and performance: an organizational perspective. Journal of Services Marketing, 2(20),136-147.

49. McGrath, G.R. \& MacMillan, I. C. (2000). Entrepreneurial Mindset: Strategies for Continuously Creating Opportunity in an Age of Uncertainty. Harvard Business School Press Books.

50. Mukherjee, A. \& Malhotra, N. (2006). Does Role Clarity Explain Employee-Perceived Service Quality? A study of antecedents and consequences in call centres. International Journal of Service Industry Management, 17 (5), 444-473.

51. Ollila, S. (2008). Strategic Support for Managers by Management Supervision. Leadership in Health Services, 1(21), 1751-1879.

52. Parasuraman, A., Zeithaml, V.A. \& Berry, L.L. (1996). The Behavioral Consequences of Service Quality. Journal of Marketing, 60(1), 31-46.

53. Peters, T. \& Waterman, R.H. (1982). In Search of Excellence. Lessons from America's Best-Run Companies, A Warner Communications Company, New York, USA.

54. Porter, M. (1996). "What is strategy?" in Ulrich, D. (Ed.), Delivering Results: A New Mandate for Human Resource Professionals, Harvard Business School Publishing, Boston, MA. 93-142.

55. Prieto, I. M., \& Revilla, E. (2006). Learning Capability and Business Performance: a Non-Financial and Financial Assessment, The Learning Organization, 13(2), 166 - 185.

56. Riahi-Belkaoui, A. (2003). Intellectual Capital and Firm Performance of US Multinational Firms - A Study of The Resource-based and Stakeholder Views", Journal of Intellectual Capital, 2(4), 215-226.

57. Robbins, S.P. (2001). Perilaku Organisasi Jilid I. Alih bahasa: Hadyana Pujaatmaka dan Benyamin Molan, Prenhallindo, Jakarta.

58. Rowe, W.G. (2001). Creating wealth in Organizations: the role of strategic leadership. Academy of Management Executive, 15(1), 81-94.

59. Sanders, T.J. \& Davey, K.S. (2011). Out of the leadership theory jungle: a proposed meta-model of strategic leadership. Proceedings of the Academy of Strategic Management, 10(1), 41-46. 
60. Sanchez, R. \& Heene, A. (1997).”Competence-based strategic management: concepts and issues for theory, research and practice", in Heene, A. and Sanchez, R. (Eds), Competence-based Strategic Management, John Wiley \& Sons, Chichester, pp. 3-42.

61. Sanchez, R. (2001), "Managing knowledge into competence: the five learning cycles of the competent organization", in Sanchez, R. (Ed.), Knowledge Management and Organizational Competence, Oxford University Press, Oxford, pp. 3-37.

62. Sanchez, R. \& Heene, A. (2004). The New Strategic Management: Organization, Competition and Competence, John Wiley \& Sons, New York, NY.

63. Sanchez, R. (2004). Understanding competence-based management: identifying and managing five modes of competence. Journal of Business Research, 57, 518-32.

64. Serfontein, J.J. (2009). The impact of strategic leadership on the operational strategy and performance of business Organisations in South Africa. DBM thesis, University of Stellenbosch, Stellenbosch.

65. Sirgy, J. M. (2002). Measuring Corporate Performance by Building on The Stakeholders Model of Business Ethics", Journal of Business Ethics, 3 (35),143-162.

66. Soehendro, B., 1996, Kerangka Pengembangan Pendidikan Tinggi Jangka Panjang 1996-2005, Proyek Pengembangan Staf dan Sarana PerguruanTinggi (PPS2PT), Jakarta.

67. Sparrow, P.R. \& Hodgkinson, G.P. (2006). What is Strategic Competence and Does It Matter? Exposition of the Concept and A Research Agenda. Center for Advance Human Resource Studies.Working Paper, 1-44.

68. Spencer, L. \& Spencer, M. (1993). Competence at work. New York: John Wiley.

69. Stogdill, R.M., Coons, A.E. (1957). Leader Behavior it's Description and Measurement. Ohio: Bureau of Business Research, The Ohio State University, 88, 1-27.

70. Sveiby, K-E. (1990). The Power and Management in an Expert Organization, Gummerus Kirjapaino Oy, Helsinki.

71. Tangem, S. (2004). Performance Measurement: From Philosophy to Practice. International Journal of Productivity and Performance Management, 8 (53), 726-737.

72. Teece, D. J., Pisano, G., Shuen, A. (1997). Dynamic Capabilities and Strategic Management.Strategic Management Journal, 18 (7), 509-533.

73. Tjiptono, F., Diana, A. (2005). Total Quality Management, Yogyakarta, Andi Press.

74. Trejo, D., Patil, S., Anderson, S., Cervantes, E. (2002). Framework for Competency and Capabilities Assessment for Resource Allocation. Journal of Management In Engineering, 1 (18), 44-49.

75. Urban, W. (2012). Organizational Service Orientation as A Quality Predictor in Services.Journal of Quality Management Practices, 101-120.

76. Vathanophas, Thai-ngam. (2007). Competency requirements for effective Job performance in the Thai Public Sector. Contemporary Management Research, 3(1), 45-70.

77. Veithzal R. (2004). Kepemimpinan dan Perilaku Organisasi (edisi kedua).Raja Grafindo Persada, Jakarta.

78. Wahlers, J.L., James, F.C. (1994). Competitive Factors and Performance Measurement: Applying the Theory of Constraints to Meet Customers Needs. International Journal of Production Economics, 2(1), 229-240.

79. Walker, J. (2007). Service climate in New Zealand English language centres. Journal of Educational Administration, 3(45), 315-337.

80. Yoon, S.J., Choi, D.C. \& Park, J.W. (2007). Service Orientation: Its Impact on Business Performance in the Medical Service Industry. The Service Industries Journal, 4 (27), 371-388. 